\title{
EFFECT OF FROZEN STORAGE AND COOKING ON THE CHEMICAL CHANGES AND QUALITY OF CHICKEN MEAT
}

\author{
Shedeed,*A.,Naglaa; Shams El-Din*,M.H.A; El-Wakeil**, F.A.; \& \\ Hallabo, **S.A.S. \\ *Food Technology Dept. National Research Centre, Giza, Egypt. \\ ** Food Technology Dept, Fac. of Agric, Cairo, Egypt.
}

\begin{abstract}
This work is carried out to evaluate the effect of frozen storage and cooking methods on the quality of chicken meat. The highest moisture losses were observed in chicken breast and thigh meat samples cooked by the microwave method. Also, all the investigated cooking methods of the same samples reduced their total protein, nitrogenous compounds and total lipids, especially after boiling. The loss by cooking methods increased as the time of frozen storage increased. The extracted fat of frozen stored chicken thigh meat samples exhibited higher acid, peroxide and TBA values than those of breast fat samples after all cooking methods. The highest losses of essential, nonessential, total amino acids and unsaturated fatty acids were found in frozen stored chicken breast and thigh meat samples cooked by roasting. Moreover, the lowest losses of the same amino and fatty acids were noticed in the same samples cooked by pressure cooking. The results indicated that either fresh or frozen stored chicken breast and tight meat samples cooked by boiling and pressure cooking methods were significantly with better for tenderness and juiciness than samples cooked by other cooking samples.
\end{abstract}

Key words: Chicken meat, Chemical composition, Cooking methods, Frozen storage, amino acids, Fatty acids, Sensory evaluation.

\section{INTRODUCTION}

The quality of raw or frozen stored cooked meat depends essentially on the composition and stability of the lipid constituents. Shams El-Din and Bayoumy, (1990 a) \& Nam, et al., (2001). During thermal processing, as a result of thermal denaturation, the meat proteins contract, leading to a substantial weight loss which can be up to $20-40 \%$ of the initial weight, mainly in the form of water and fat Pan and Singh, (2001)\& Oroszvári et al., (2005). Water can be lost either by evaporation through the crust or as drip, while fat is only lost exuded from the meat as drip Shilton et al, (2002)\& Oroszvári et al.,( 2006) or as primary lipid oxidation products (e.g. lipid hydroperoxides and hexanal) and secondary lipid oxidation products (e.g. thiobarbituric acid reactive substances, TBARS) in chicken Lau \& King, (2003). The thiobarbituric acid (TBA) test has been widely used for measuring oxidative rancidity in fat containing food, especially fish and meat. Cortinas et al., (2005) \& Rahman et $\boldsymbol{a l}$ (2009). This test was considered as a sensitive test for the decomposition products of highly unsaturated fatty acids which do not appear in peroxide determination Melton, (1983). Total soluble nitrogen (T.S.N.) soluble protein nitrogen (S.P.N) and soluble actomyosim nitrogen (S.A.N) percentages of chicken white and dark meat samples markedly decreased but the non protein nitrogen (N.P.N) increased as the time of frozen storage progressed and at any time of frozen storage Abd El-Baki et al, (1983); Abd El-Wahed (1986) \& Moawad (1995). Minor changes occurred in the fatty acid composition of the triglycerides during frozen storage and cooking of either chicken white or dark meats Igene et al. (1981), Candela et al., (1996) \& Capita, et al. (2003). Cooking of frozen stored chicken meat increased the losses in essential, non-essential

Fayoum J. Agric. Res. \& Dev., Vol.24, No.2, July, 2010 
and total amino acids, which might be attributed to their loss with drippings separated during cooking as well as by the possible heat destruction of some proteins Abd ElWahed (1986) \& Moawad (1995). Consumer acceptance of meat depends on its quality, which is influenced by a series of factors ranging from the physical and chemical to the histological properties and processing procedure of meat Alvarado \& Sans,(2004).Tenderness has been noted as the most important factor in consumer perception of quality of meat products Lwasaki, et al. (2009).

This work was undertaken to evaluate the effect of frozen storage up to 6 months and different cooking method on the chemical composition, stability, fatty and amino acids composition and organolyptic evaluation of chicken white and dark meat.

\section{MATERIALS AND METHODS}

Materials :

Thirty chicken broilers used in this study were obtained from El-Zomor farm, Kalyoubia, Egypt. Their weight ranged between (1000-1200 g) and the average age was 8 weeks.

\section{Preparation of chicken meat parts:}

Chickens were slaughtered, plucked by hand, cleaned and washed with water. The wings, neck and heads were removed by hand. The carcasses were then cut into four parts (two breast pieces and two thighs pieces).Fresh chicken unskinned thighs and breasts meat were packaged in polyethylene bags and frozen at $-20^{\circ} \mathrm{C}$ for different storage periods up to 6 months. At designated storage periods, samples were removed from frozen storage, thawed for $3 \mathrm{hrs}$ at room temperature and immediately cooked.

\section{Cooking methods:}

Chicken parts (thighs and breasts) were cooked by the following methods:

- Boiled in sufficient amounts of water to cover it at ratio 2: 1 (water : chicken) for 30 minutes.

- Cooked for 20 minutes in a pressure cooker

- Roasted by using a preheated conventional electric oven to $180{ }^{\circ} \mathrm{C}$ for 60 minutes

- Cooked in a Gold Star Microwave Oven (Model ER-535 MD) (2450 MHz) on a high power level for 20 minutes, 10 minutes on one side and 10 on the other.

Thawed, raw and cooked chicken meat parts were manually deboned, cut into pieces and ground twice using a Hobart meat grinder. The prepared samples were used for immediate analysis.

Analytical Methods:

Moisture and lipids were determined according to the methods recommended by the A.O.A.C.(2005).

Lipids were extracted from chicken meat samples by the method suggested and adopted by Bligh \& Dyer (1959). Acid and peroxide values were determined according to the methods of the A.O.A.C. (2005).

Thiobarbituric acid (TBA) was determined according to the method described by Egan et al., (1981).

Fatty acids determination:

The method described by Metcalfe et al. (1963) \& Metcalfe \& Wang (1981) was applied for the preparation of fatty acids methyl esters. A Pye Unicum GLC apparatus (series 104 Model 64, equipped with a hydrogen flame ionization detector available at the central lab., Faculty of Agriculture, Cairo University), was used for detecting the fatty acids. The following operating conditions were carefully selected to ensure precise calculations of the peaks and for separation of the peaks of the fatty acids.

Fayoum J. Agric. Res. \& Dev., Vol.24, No.2, July, 2010 
Detector :Flame ionization, Column: $1.5 \mathrm{~m}$ x $0.4 \mathrm{~mm}$ coiled glass column packed with $10 \%$ polyethylene glycol adipate on celite (100-120 mesh), Carrier gas flow :Nitrogen $30 \mathrm{ml} . / \mathrm{min}$. - Hydrogen $33 \mathrm{ml} . / \mathrm{min}$.

- Air $330 \mathrm{ml} . / \mathrm{min}$, Injector temperature $: 220^{\circ} \mathrm{C}$, Chart speed $: 1 \mathrm{~cm} / 2 \mathrm{~min}$, Column temperature: Isothermal $190^{\circ} \mathrm{C}$, Attenuation $: 32 \times 10^{2}$, Detector temperature: $200^{\circ} \mathrm{C}$.

The standard fatty acid mixture solution was used as primary reference during all the analyses carried out in this investigation. Relative percentage fatty acids were automatically calculated in the apparatus according to the area of each fatty acid to the area of the total fatty acids of sample.

Total nitrogen (T.N.) was determined in the studied chicken meat samples using the micro Kjeldahl procedure according to the method recommended in the A.O.A.C.(2005). Protein content was calculated by multiplying the nitrogen content by 6.25 , and the results expressed as \% protein.

Nitrogenous compounds:

Total soluble nitrogen (T.S.N.), soluble protein nitrogen (SPN), and soluble actomyosin nitrogen (SAN) were determined according to the methods of the A.O.A.C. (2005). Non-protein nitrogen (N.P.N.) was calculated according to Bodwell and McClain (1971), using the following equation: N.P.N. = T.S.N. - S.P.

Amino acids determination:

Amino acids, other than tryptophan, proleine, cystine and methionine, were determined at the central laboratory for Food and Feed belonging to the Agriculture Research Center of the Egyptian Ministry of Agriculture. Acid hydrolysis was performed in sealed ampoules for the determination of amino acids.High Performance Amino Acid Analyzer (Beckman System 7300 and Data system 7000) was used as described by Moore et al. (1958) \& Widner\& Eggum (1966).

The results of fatty and amino acids composition were quite similar, therefore the experiments were carried out twice.

\section{Sensory evaluation and statistical analysis:}

Frozen cooked chicken meat parts (breast and thigh) were organolyptically evaluated by ten panelists from the Food Science Department, National Research Centre, Dokki, Giza, Egypt. All samples were evaluated for test, juiciness, tenderness, flavor and palatability using ten points hedonic scale on which scale on which a score of 10 represented attributes most liked; 5 represented attributes at an acceptable margin and 1 represented attributes most disliked. The mean values for each of the parameters in the organoleptic analysis were subjected to statistical analysis using analysis of variance and least significant difference (L.S.D.) as reported by Snedecor \& Cochran (1989).

\section{RESULTS AND DISCUSSION}

Effect of frozen storage and cooking methods on the chemical composition of chicken meat:

Changes in moisture content reflect the extent of water holding capacity. Data in Tables (1 and 2) showed the effect of frozen storage and cooking methods on the moisture content in chicken breast and thigh meat samples. These results reveal that all cooking methods used reduced the moisture content of the frozen stored meat. Moreover, the moisture loss in the frozen stored chicken breast and thigh meats was higher than that in the same fresh cooked samples by all studied cooking methods. On the other hand, the loss in moisture by cooking increased as the time of frozen storage of chicken parts increased. Chicken breast and thigh meat samples, cooked by all the investigated cooking methods, had the lowest moisture contents after six months of frozen storage. Frozen stored chicken breast and thigh meat samples for 6 months and

Fayoum J. Agric. Res. \& Dev., Vol.24, No.2, July, 2010 
cooked by pressure, had higher moisture contents than the same samples cooked by the other cooking methods. The highest moisture losses (\%) were observed in chicken breast and thigh meat samples cooked by microwave after 6 months of frozen storage being 20.70 and $22.65 \%$, respectively, as compared to moisture contents $\%$ of the same fresh raw samples. The reduction in water holding capacity could lower the moisture content in either storage or cooking chicken meat samples Abd El-Wahed (1986) \& Oroszvári et al., (2005).

Meat protein is a major constituent, which affects meat quality and nutritive value. Total nitrogen and protein of frozen cooked chicken breast and thigh meat samples are represented in Tables (1 and 2).At the third month of frozen storage a higher decrease in total nitrogen and protein was observed in either chicken breast or thigh meat samples, especially after boiling. For instance, total nitrogen and protein of boiled breast and thigh meat samples, after 3 months of frozen storage, were 11.97 and $74.81 \%$ as well as 10.69 and $66.81 \%$ respectively. Meanwhile, the lowest decrease in total nitrogen and protein was found in chicken breast and thigh meat samples cooked by the pressure method after 3 and 6 months of frozen storage, as compared to the other cooking methods. However, microwave and roasting cooking methods retained approximately the same contents of total nitrogen and protein in chicken breast and thigh meat samples cooked by the two studied methods after 3 and 6 months of frozen storage. The same results showed that at any frozen storage time, cooked chicken breast meat samples exhibited higher contents of total nitrogen and protein as compared to those of the cooked chicken thigh meat samples cooked by any of the studied cooking method. The total nitrogen and protein content losses in the chicken breast and thigh meat samples, cooked during frozen storage, were higher than those in the same fresh cooked samples by any cooking method. That is due to the action of proteolytic meat enzymes. In this respect Abd El-Wahed (1986) \& Moawad (1995) indicated that proteolytic enzymes of meat tissues were still active during frozen storage and were responsible for the partial hydrolysis of protein.

Results in Tables (1 and 2) also show the total soluble nitrogen (T.S.N.), soluble protein nitrogen (S.P.N.), soluble actomyosin nitrogen (S.A.N.) and non-protein nitrogen (N.P.N.) for cooked chicken breast and thigh meat samples during frozen storage. Chicken breast meat samples, cooked by any cooking method showed higher T.S.N., S.P.N., S.A.N. and N.P.N. than those of chicken thigh meat samples at any tested frozen storage time. The same results also indicated that all cooking methods reduced the previously mentioned nitrogenous compounds except N.P.N. in the frozen stored chicken breast and thigh meat samples, especially after 6 months. From the previously mentioned statement, it could be concluded that boiling exhibited the highest reduction in T.S.N., S.P.N., and S.A.N. of either frozen stored chicken breast or thigh meat samples after 3 and 6 months, followed in a decreasing order by roasting, microwave and pressure cooking. On the other hand, cooking of frozen stored chicken meat exhibited a higher loss in T.S.N., S.P.N. and S.A.N. compared to that of the same fresh cooked meat. After 3 and 6 months of frozen storage, the losses in T.S.N. by boiling were 58.55 and $62.42 \%$ for breast meat samples, compared to \% for fresh breast meat, while for the thigh meat samples these were 51.98 and $59.34 \%$ respectively. The reduction in S.P.N. could be attributed to the denaturation of protein by the effect of heat as mentioned by Harrison (1980). It was also noticed that cooking of chicken meat by pressure caused minimum loss in S.P.N. being: 30.4 and $42.2 \%$ after 3 and 6 months for breast meat as well as 23.59 and $42.09 \%$ for thigh meat, respectively. These results are in agreement with Abd El-Wahed (1986). Pressure cooking retained 13.49 and $15.20 \%$ of their original S.A.N., compared to \% for fresh thigh samples respectively after 6 months of frozen storage cooked chicken breast and

Fayoum J. Agric. Res. \& Dev., Vol.24, No.2, July, 2010 
Table 1

Fayoum J. Agric. Res. \& Dev., Vol.24, No.2, July, 2010 
Table 2

Fayoum J. Agric. Res. \& Dev., Vol.24, No.2, July, 2010 
thigh meat samples. The corresponding values of cooked breast and thigh meat samples by boiling were only 10.95 and $14.45 \%$, respectively. Microwave and roasting cooking methods retained approximately the same contents of T.S.N., S.P.N. and S.A.N. in chicken breast and thigh meat samples after 3 and 6 months of frozen storage. Furthermore, the non-protein nitrogen of the frozen stored chicken meat samples increased by all cooking methods. The N.P.N. fraction of cooked chicken meat samples under investigation was found to increase as the time of frozen storage increased, with higher levels in breast meat than in thigh meat samples. These results reflect higher proteolysis and protein breakdown products in breast meat than in thigh meat. Similar findings were reported by Abd El-Wahed (1986) \& Moawad (1995).

Concerning the fat contents; Tables $(1 \& 2)$ reveal that all cooking methods reduced the total lipids content for both investigated frozen stored breast and thigh meat samples (on dry weight basis). It could be concluded that roasting exhibited the highest loss in total lipids of either frozen stored chicken breast or thigh meat samples for 3 and 6 months, followed in a decreasing order by microwave, boiling and pressure cooking. These losses in total lipids content for the frozen stored and cooked chicken meat samples could be attributed to both enzymatic and or oxidative reactions or to leaching in the drippings Morsi et al., (1975) \& Moawad, (1987).

Chemical properties of the fat extracted from frozen stored chicken meat after cooking:

Acid, peroxide and TBA values reflect directly the changes that occurred in fat during freezing and cooking, which might affect the eating quality of meat. The acid, peroxide and TBA values of the fat extracted from cooked chicken breast and thigh meats during frozen storage are given in Table (3). The data in this Table showed noticeable increases in the acid, peroxide and TBA values, especially in the case of roasted frozen stored chicken breast or thigh meat samples. It is also apparent that, the fat of frozen stored chicken thigh meat samples exhibited higher values than those of breast samples after all cooking methods. The greater differences between cooking methods of frozen stored chicken meat samples could be attributed to the storage and cooking conditions, especially time and temperature. Jensen et al., (1997); Grau et al., (2001) a and b \& Cortinas, (2005). Shams El-Din and Ibrahim (1990b) observed that cooking increased the free fatty acid levels. It has been also reported that cooking of beef stored beef at $-20^{\circ} \mathrm{C}$ for 12 weeks caused a significant increase in its peroxide and TBA values than fresh cooked beef meat Moawad, (1987). Meanwhile, Abd ElWahed (1986) reported that, cooking of either fresh or frozen chickens by different methods reduced the peroxide value of the extracted fat. The decrease in peroxide value during cooking might be attributed to steam distillation, which could have removed the formed volatile peroxides Kopp, (1973) \& Rahman et al ., (2009). These fluctuating results could be due to the problem of sample autoxidation during peroxide and TBA analysis, associated with the probable enhancing effect by higher levels of oxidized lipids in the studied cooked meat samples Pikul et al., (1984).

Effect of cooking methods on fatty acid composition of frozen stored chicken meat:

Chicken lipids are characterized by relatively high levels of unsaturated fatty acids which are considered as a positive and healthy aspect by consumers Tables ( 4 \& 5).These results are in agreement with Shams El-Din \& Ibrahim (1990 b) \& Wood et al., (2003). From these results in these Tables it could be observed that the total unsaturated fatty acids of both frozen stored chicken meat samples were found to decrease after all the cooking methods, especially after roasting. Lowest loss in total unsaturated fatty acids was found in the frozen stored chicken breast and thigh meat samples cooked by pressure Since fatty acids (saturated and unsaturated) are

Fayoum J. Agric. Res. \& Dev., Vol.24, No.2, July, 2010 
Table 3

Fayoum J. Agric. Res. \& Dev., Vol.24, No.2, July, 2010 
Table 4

Fayoum J. Agric. Res. \& Dev., Vol.24, No.2, July, 2010 
Table 5

Fayoum J. Agric. Res. \& Dev., Vol.24, No.2, July, 2010 
determined and calculated to represent mathematically $100 \%$, the actual decrease in total unsaturated fatty acids will consequently apparent theoretical increase in saturated fatty acids which does not represent an actual increase in total saturated fatty acids..

Effect of cooking methods on amino acid composition of frozen stored chicken meat:

Amino acid contents of frozen stored chicken meat samples as affected by cooking methods are shown in Tables $(6 \& 7)$ from these Tables it could be observed that, cooked frozen stored chicken breast and thigh meat samples for 6 months reduced the total amino acids, the quantity of these amino acids varied according to the cooking method applied. A marked reduction took place in glutamic acid and arginine was also showed as well as sulpher-amino acids in both investigated chicken meat samples. On the other hand, a slight decline in the other amino acid was noticed. The highest losses of essential, non-essential and total amino acids were found in frozen stored chicken breast and thigh meat samples cooked by roasting. Meanwhile, the lowest losses of essential, non-essential and total amino acids were noticed in the same samples cooked by pressure. This reduction of amino acid contents might be attributed to their losses with drippings separated during cooking as well as by the heat destruction as mentioned by Moussa (1981); Abd El-Wahed (1986) \& Moawad (1987).

Table 6. Effect of cooking methods on amino acids composition of frozen stored chicken white meat (breast).

\begin{tabular}{|c|c|c|c|c|c|c|c|c|}
\hline \multirow{4}{*}{$\begin{array}{l}\text { Amino acids } \\
(\mathrm{g} / 16 \mathrm{~g} \mathrm{~N})\end{array}$} & \multicolumn{8}{|c|}{ Cooking methods } \\
\hline & \multirow{2}{*}{\multicolumn{2}{|c|}{$\begin{array}{c}\text { Boiling } \\
\begin{array}{c}\text { Storage period } \\
\text { (month) }\end{array}\end{array}$}} & \multirow{2}{*}{\multicolumn{2}{|c|}{$\begin{array}{c}\text { Pressure } \\
\begin{array}{c}\text { Storage period } \\
\text { (month) }\end{array}\end{array}$}} & \multirow{2}{*}{\multicolumn{2}{|c|}{$\begin{array}{c}\text { Microwave } \\
\text { Storage period } \\
\text { (month) }\end{array}$}} & \multirow{2}{*}{\multicolumn{2}{|c|}{$\begin{array}{c}\text { Roasting } \\
\begin{array}{c}\text { Storageperiod } \\
\text { (month) }\end{array}\end{array}$}} \\
\hline & & & & & & & & \\
\hline & 0 & 6 & 0 & 6 & 0 & 6 & 0 & 6 \\
\hline \multicolumn{9}{|c|}{ Essential amino acids } \\
\hline Threonine & 2.92 & 2.58 & 2.95 & 2.60 & 3.01 & 2.62 & 2.93 & 2.56 \\
\hline Cysteine & 0.96 & 0.60 & 0.98 & 0.62 & 0.93 & 0.58 & 0.87 & 0.55 \\
\hline Valine & 5.51 & 4.81 & 5.53 & 4.87 & 5.42 & 4.72 & 5.24 & 4.51 \\
\hline Methionine & 2.36 & 1.70 & 2.42 & 1.75 & 2.25 & 1.69 & 2.16 & 1.01 \\
\hline Isoleucine & 4.85 & 4.61 & 4.91 & 4.66 & 4.86 & 4.58 & 4.80 & 4.49 \\
\hline Leucine & 6.93 & 6.11 & 6.95 & 6.10 & 7.02 & 6.02 & 6.95 & 5.92 \\
\hline Tyrosine & 2.21 & 1.70 & 2.27 & 1.76 & 2.11 & 1.65 & 1.98 & 1.61 \\
\hline Phenylalanine & 3.24 & 2.93 & 3.26 & 2.91 & 3.15 & 2.86 & 3.11 & 2.80 \\
\hline Lysine & 6.98 & 6.15 & 7.08 & 6.21 & 6.91 & 6.10 & 6.85 & 5.95 \\
\hline Total E.A.A. & 35.96 & 31.19 & 36.35 & 31.48 & 35.66 & 30.82 & 34.89 & 30.03 \\
\hline \multicolumn{9}{|c|}{ Non-essential amino acids } \\
\hline Aspartic acid & 8.72 & 8.05 & 8.83 & 8.16 & 8.64 & 7.85 & 8.55 & 7.91 \\
\hline Serine & 3.06 & 2.67 & 3.11 & 2.75 & 3.02 & 2.59 & 2.98 & 2.55 \\
\hline Glutamic acid & 15.81 & 13.62 & 15.90 & 13.93 & 15.81 & 13.57 & 15.74 & 13.50 \\
\hline Proline* & -- & -- & -- & -- & -- & -- & -- & -- \\
\hline Glysine & 4.96 & 4.64 & 5.02 & 4.72 & 4.93 & 4.58 & 4.85 & 4.47 \\
\hline Alanine & 5.41 & 4.82 & 5.46 & 4.96 & 5.30 & 4.80 & 5.26 & 4.68 \\
\hline Histidine & 3.58 & 3.20 & 3.61 & 3.25 & 3.48 & 3.15 & 3.39 & 3.10 \\
\hline Arginine & 5.90 & 5.11 & 5.93 & 5.18 & 5.81 & 4.93 & 5.77 & 4.79 \\
\hline Total Non.E.A.A. & 47.44 & 42.11 & 47.86 & 42.95 & 46.99 & 41.47 & 46.54 & 41.00 \\
\hline
\end{tabular}

Values are the average of 2 experiments.

Fayoum J. Agric. Res. \& Dev., Vol.24, No.2, July, 2010 
Sensory evaluation of stored chicken meat cooked by different methods.

With respect to sensory evaluation, the eating quality characteristics of the cooked (fresh and frozen stored) chicken breast and thigh meat samples by different cooking methods were assessed and the obtained results are presented in Table (8). The same Table showed that the cooked (either fresh or frozen stored) chicken breast and thigh meat sample by boiling methods had higher score for tenderness .A significant changes $(p<0.01)$ in tenderness better either fresh or frozen stored chicken breast and thigh meat samples cooked by boiling and pressure methods and the same samples cooked by microwave and roasting methods, could be due to the loss of water holding capacity. These results agree with Self et al., (1990). The fresh and frozen stored chicken breast meat samples, cooked by microwave and roasting, showed no significant differences $(\mathrm{p}<0.01)$ between them for tenderness. Castaneda et al., (2005) \& Mehaffey et al., (2006) reported that age, sex, location, deboning time and cooking method could influence the ultimate tenderness of broiler meat.

Referring to the same Table, it could be noticed that the fresh or frozen by cooked boiling or pressure cooking had higher scores for juiciness as compared with the same samples cooked by microwave and roasting. These results confirm the findings of Barbeau \& Schnept (1989). Meanwhile, the fresh and frozen stored chicken breast meat samples, cooked by boiling and pressure, showed no significant differences $(\mathrm{p}<0.01)$ between them for juiciness. However, significant changes $(\mathrm{p}<0.01)$ were obtained for juiciness of fresh cooked chicken breast meat samples when cooked by microwave and roasting methods.

Moreover, the fresh and frozen stored chicken breast and thigh meat samples cooked by microwave and roasting showed significant differences $(p<0.01)$ for flavor as compared with the same samples cooked by boiling or pressure. Flavor scores were associated with tenderness and juiciness in both white and dark meats regardless of the variable packaging or the cooking treatment. Panelists often commented that flavor was of the most difficult factors to judge Culotta \& Chen (1973). Likewise, Risch (1989) found that foods prepared by using a microwave oven usually generated less desirable flavors than those prepared by the conventional oven.

Concerning palatability, it could be concluded that fresh and frozen stored chicken breast and thigh meat samples cooked by microwave and roasting, showed significant changes $(\mathrm{p}<0.01)$ in palatability as compared with the same samples cooked by boiling or pressure. In this respect Harrison (1980) \& Alvarado \& Sans (2004) pointed out that processing conditions and cooking methods are known to affect the palatability of cooked meat and it has been suggested that higher surface temperature in microwave cooked meat may lead to excessive protein denaturation, where sensory perception of meat juiciness is related to the degree of wetness perceived as the first few chews are taken. However, no significant differences $(p<0.01)$ were observed on palatability for fresh and frozen stored chicken breast and thigh meat samples cooked by any cooking method. Furthermore, the scores of all the sensory parameters were found to decrease as the time of frozen storage of the investigated chicken parts increased. The above mentioned results and conclusions are in accordance with the findings of Shireva et al. (1979).

In general, the results in Table (8) indicated that, either fresh or frozen stored chicken breast and thigh meat samples cooked by boiling and pressure cooking showed significant difference $(\mathrm{p}<0.01)$ for tenderness and juiciness as compared with the same samples cooked by microwave and roasting. Meanwhile, the latter two cooking methods caused significant changes $(\mathrm{p}<0.01)$ in flavor and palatability for the same samples as compared with both boiling and pressure cooking methods.

Fayoum J. Agric. Res. \& Dev., Vol.24, No.2, July, 2010 
EFFECT OF FROZEN STORAGE AND COOKING ON THE

171

Table 7. Effect of cooking methods on amino acids composition of frozen stored dark meat (thigh).

\begin{tabular}{|c|c|c|c|c|c|c|c|c|}
\hline \multirow{4}{*}{$\begin{array}{l}\text { Amino acids } \\
(\mathrm{g} / 16 \mathrm{~g} \mathrm{~N})\end{array}$} & \multicolumn{8}{|c|}{ Cooking methods } \\
\hline & \multirow{2}{*}{\multicolumn{2}{|c|}{$\begin{array}{c}\text { Boiling } \\
\begin{array}{c}\text { Storage period } \\
\text { (month) }\end{array}\end{array}$}} & \multirow{2}{*}{\multicolumn{2}{|c|}{$\begin{array}{c}\text { Pressure } \\
\begin{array}{c}\text { Storage period } \\
\text { (month) }\end{array}\end{array}$}} & \multirow{2}{*}{\multicolumn{2}{|c|}{$\begin{array}{c}\text { Microwave } \\
\begin{array}{c}\text { Storage period } \\
\text { (month) }\end{array}\end{array}$}} & \multirow{2}{*}{\multicolumn{2}{|c|}{$\begin{array}{c}\text { Roasting } \\
\begin{array}{c}\text { Storage period } \\
\text { (month) }\end{array}\end{array}$}} \\
\hline & & & & & & & & \\
\hline & $\mathbf{0}$ & 6 & 0 & 6 & $\mathbf{0}$ & 6 & 0 & 6 \\
\hline \multicolumn{9}{|c|}{ Essential amino acids } \\
\hline Threonie & 2.65 & 2.32 & 2.61 & 2.35 & 2.56 & 2.27 & 2.44 & 2.20 \\
\hline Cysteine & 1.17 & 0.63 & 1.10 & 0.66 & 1.14 & 0.61 & 0.97 & 0.55 \\
\hline Valine & 4.36 & 3.85 & 4.35 & 3.90 & 4.17 & 3.76 & 4.01 & 3.64 \\
\hline Methionine & 1.83 & 1.22 & 1.92 & 1.24 & 1.85 & 1.18 & 1.80 & 1.15 \\
\hline Isoleucie & 4.59 & 4.34 & 4.73 & 4.35 & 4.51 & 4.25 & 4.35 & 4.13 \\
\hline Leucine & 6.41 & 5.48 & 6.52 & 5.51 & 6.36 & 5.40 & 6.21 & 5.22 \\
\hline Tyrosine & 2.14 & 1.72 & 2.10 & 1.73 & 2.03 & 1.71 & 1.95 & 1.64 \\
\hline Phenylalanine & 2.97 & 2.55 & 3.02 & 2.60 & 2.95 & 2.49 & 2.83 & 2.41 \\
\hline Lysine & 6.78 & 5.71 & 6.86 & 5.78 & 6.73 & 5.56 & 5.65 & 5.40 \\
\hline Total E.A.A. & 32.90 & 27.82 & 33.21 & 28.12 & 32.30 & 27.23 & 31.21 & 26.34 \\
\hline \multicolumn{9}{|c|}{ Non-essential aminoacids } \\
\hline Aspaacid & 8.91 & 8.15 & 5.96 & 8.24 & 8.75 & 8.02 & 8.59 & 7.88 \\
\hline Serine & 2.93 & 2.60 & 2.97 & 2.71 & 2.96 & 2.51 & 2.87 & 2.42 \\
\hline Glutamic acid & 16.16 & 13.79 & 16.21 & 14.06 & 15.95 & 13.65 & 15.83 & 13.54 \\
\hline Proline* & -- & -- & -- & -- & -- & -- & -- & -- \\
\hline Glysine & 6.25 & 5.63 & 6.32 & 5.70 & 6.18 & 5.53 & 6.12 & 5.47 \\
\hline Alanine & 5.76 & 5.12 & 5.81 & 5.18 & 5.72 & 5.00 & 5.61 & 4.90 \\
\hline Histidine & 2.39 & 1.78 & 2.45 & 1.85 & 2.34 & 1.70 & 2.26 & 1.63 \\
\hline Arginine & 5.18 & 4.20 & 5.23 & 4.25 & 5.10 & 4.04 & 4.94 & 3.95 \\
\hline Total & 47.58 & 41.27 & 47.95 & 42.00 & 47.00 & 40.45 & 46.22 & 39.79 \\
\hline Non E.A.A. & & & & & & & & \\
\hline
\end{tabular}

Values are the average of 2 experiments

Table 8. Statistical analysis of sensory scores (L.S.D.) of cooked chicken breast and thigh meat.

\begin{tabular}{|c|c|c|c|c|c|c|c|c|c|c|c|c|c|}
\hline \multirow{3}{*}{$\begin{array}{l}\text { Sensory } \\
\text { characteristics }\end{array}$} & \multirow{2}{*}{\multicolumn{3}{|c|}{$\begin{array}{c}\text { Boiling } \\
\begin{array}{c}\text { Storage periods } \\
\text { (month) }\end{array} \\
\end{array}$}} & \multirow{2}{*}{\multicolumn{3}{|c|}{$\begin{array}{c}\text { Pressure } \\
\begin{array}{c}\text { Storage } \\
\text { periods(month) }\end{array} \\
\end{array}$}} & \multirow{2}{*}{\multicolumn{3}{|c|}{$\begin{array}{c}\text { Microwave } \\
\begin{array}{c}\text { Storage periods } \\
\text { (month) }\end{array}\end{array}$}} & \multirow{2}{*}{\multicolumn{3}{|c|}{$\begin{array}{c}\text { Roasting } \\
\begin{array}{c}\text { Storage periods } \\
\text { (month) }\end{array}\end{array}$}} & \multirow{3}{*}{$\begin{array}{c}\text { L.S.D. } \\
(\mathbf{p}<0.01)\end{array}$} \\
\hline & & & & & & & & & & & & & \\
\hline & $\mathbf{0}$ & 3 & 6 & $\mathbf{0}$ & 3 & 6 & $\mathbf{0}$ & 3 & 6 & $\mathbf{0}$ & 3 & 6 & \\
\hline \multicolumn{14}{|c|}{ Whitemeat (breast) } \\
\hline Tenderness & $8.5^{\mathrm{a}}$ & $8.2^{\mathrm{ab}}$ & $7.9^{\mathrm{b}}$ & $8.3^{\mathrm{ab}}$ & $8.1^{\mathrm{ab}}$ & $7.8^{\mathrm{b}}$ & $6.9^{\mathrm{c}}$ & $6.7^{\mathrm{c}}$ & $6.4^{\mathrm{c}}$ & $6.9^{\mathrm{c}}$ & $6.8^{\mathrm{c}}$ & $6.5^{\mathrm{c}}$ & 0.56593 \\
\hline Juiciness & $8.1^{\mathrm{a}}$ & $8.0^{\mathrm{a}}$ & $7.8^{\mathrm{a}}$ & $8.1^{\mathrm{a}}$ & $7.8^{\mathrm{a}}$ & $7.7^{\mathrm{a}}$ & $6.6^{\mathrm{bc}}$ & $6.3^{\mathrm{bcd}}$ & $6.0^{\mathrm{d}}$ & $6.7^{\mathrm{b}}$ & $6.5^{\text {bcd }}$ & $6.1^{\text {cd }}$ & 0.57295 \\
\hline Flavor & $7.4^{\mathrm{d}}$ & $7.0^{\mathrm{de}}$ & $6.9^{\mathrm{e}}$ & $7.4^{\mathrm{d}}$ & $7.2^{\mathrm{de}}$ & $6.9^{\mathrm{e}}$ & $8.8^{\mathrm{ab}}$ & $8.6^{\mathrm{abc}}$ & $8.3^{\mathrm{c}}$ & $8.9^{\mathrm{a}}$ & $8.6^{\mathrm{abc}}$ & $8.4^{\mathrm{bc}}$ & 0.46730 \\
\hline Palatability & $7.0^{\mathrm{cd}}$ & $6.8^{\mathrm{cd}}$ & $6.5^{\mathrm{d}}$ & $7.1^{\mathrm{c}}$ & $6.8^{\mathrm{cd}}$ & $6.6^{\text {cd }}$ & $8.6^{\mathrm{ab}}$ & $8.4^{\mathrm{ab}}$ & $8.1^{\mathrm{b}}$ & $8.7^{\mathrm{a}}$ & $8.6^{\mathrm{ab}}$ & $8.5^{\mathrm{ab}}$ & 0.53756 \\
\hline \multicolumn{14}{|c|}{ Dark meat (thigh) } \\
\hline Tenderness & $8.4^{\mathrm{a}}$ & $8.0^{\mathrm{ab}}$ & $7.8^{\mathrm{b}}$ & $8.1^{\mathrm{ab}}$ & $7.9^{\mathrm{ab}}$ & $7.6^{\mathrm{b}}$ & $6.7^{\mathrm{cd}}$ & $6.4^{\mathrm{cd}}$ & $6.2^{\mathrm{d}}$ & $6.8^{\mathrm{c}}$ & $6.5^{\mathrm{cd}}$ & $6.4^{\mathrm{cd}}$ & 0.53143 \\
\hline Juiciness & $8.2^{\mathrm{a}}$ & $7.9^{\mathrm{ab}}$ & $7.7^{\mathrm{ab}}$ & $8.1^{\mathrm{a}}$ & $7.8^{\mathrm{ab}}$ & $7.5^{\mathrm{b}}$ & $6.5^{\mathrm{cd}}$ & $6.3^{\mathrm{cd}}$ & $6.0^{\mathrm{d}}$ & $6.6^{\mathrm{c}}$ & $6.5^{\mathrm{cd}}$ & $6.0^{\mathrm{d}}$ & 0.56010 \\
\hline Flavor & $7.6^{b}$ & $7.3^{\mathrm{bc}}$ & $7.1^{\mathrm{c}}$ & $7.6^{b}$ & $7.4^{\mathrm{bc}}$ & $7.3^{\mathrm{bc}}$ & $9.0^{\mathrm{a}}$ & $8.8^{\mathrm{a}}$ & $8.6^{\mathrm{a}}$ & $9.0^{\mathrm{a}}$ & $8.9^{\mathrm{a}}$ & $8.8^{\mathrm{a}}$ & 0.44167 \\
\hline Palatability & $7.2^{\mathrm{cd}}$ & $7.0 \mathrm{~cd}$ & $6.7^{\mathrm{d}}$ & $7.4^{\mathrm{c}}$ & $7.1^{\mathrm{cd}}$ & $6.9^{\mathrm{cd}}$ & $8.7^{\mathrm{ab}}$ & $8.5^{\mathrm{ab}}$ & $8.2^{\mathrm{b}}$ & $8.8^{\mathrm{a}}$ & $8.7^{\mathrm{ab}}$ & $8.5^{\mathrm{ab}}$ & 0.59965 \\
\hline
\end{tabular}

The mean scores in raw with same letter or letters are not significantly at the $1 \%$ level of significant.

Fayoum J. Agric. Res. \& Dev., Vol.24, No.2, July, 2010 


\section{CONCLUSION}

It could be concluded that all cooking methods caused losses in total lipids, protein, nitrogen, S.P.N, SAN, unsaturated fatty acids, essential ,non-essential and total amino acids of frozen stored chicken breast and thigh meat. Also frozen stored chicken breast and thigh meat cooked by boiling and pressure were significantly better in tenderness and juiciness as compared with the same samples cooked by microwave and roasting. Meanwhile the latter two cooking methods caused significant losses $(p<0.01)$ in flavor and palatability for the same samples as compared with both boiling and pressure methods

\section{REFERENCES}

Abd El-Baki, M. M., Taha, R. A., El-Zayet, F.M.M., El-Dashiouty, A.A.\&, Fouda, Z. M. A. (1983). Influence of some pre-freezing treatments on the chemical and physical properties of chicken meat. Proc. 29th Euro. Meeting of Meat Res. Workers, Parma.

Abd El-Wahed, W.Z.M. (1986). Effect of preparation and cooking methods on the constituents and characteristics of poultry meat Ph.D. Thesis, Faculty of Agric., Cairo Univ.

Alvarado, C.Z.\&, Sans, A.R. (2004). Early postmortem injection and tumble marination effects on broiler breast meat tenderness. Poultry Science, 83: 10351038.

A.O.A.C. (2005). Official Methods of Analysis of AOAC International. 18 th ed. Published by AOAC International Gaithersburg, Maryland USA..

Barbeau, W.E.,\& Schnept, M. (1989). Sensory attributes and thiamine content of roasting chickens cooked in a microwave, convection microwave and conventional electric oven. J. Food Quality, 12, 203-213.

Bligh, R.G., \& Dyer, W.J. A (1959). Rapid method of total lipid extraction and purification. Canada J. Biochem. and Physicol., 37, 911-914.

Bodwell, C.E.\&, McClain P.E. (1971). Chemistry of animal tissues in: The Science of Meat and Meat Products, $2^{\text {nd }}$ ed. Freeman W.H. and Company, San Fransisco and London.

Candela, M., Astiasaran, I.\&, Bello, J., (1996). Effect of frying on the fatty acid profile of some meat dishes. Journal of Food Composition and Analysis, 9, 277-282.

Capita, R., Garcia-Linares, M. C., Tomé, M., Garia-Fernandez, M. C., GarciaArias, M.T.\& Sanchez-Muniz, F. J., (2003,) Deep-frying of chicken meat and chicken based product. Changes in the proximate and fatty acid compositions. Italian Journal of Food Science, 15, 225-240.

Castaneda, M. P., Hirschler, E. M.\&, Sams, A. R (2005). Early postmortem carcass trims effects on the tenderness of broiler breast. Poultry Science, 84, 951-954.

Cortinas, L., Barroeta, A. Villaverde, C., Galobart, J., Guardiola, F.\&, Baucells, M.D. (2005,). Influence of the Dietary Polyunsaturation Level on Chicken Meat Quality: Lipid Oxidation. Poultry Science 84, 48-55.

Culotta, J.T. \& Chen, T.C. (1973). Hot water and microwave energy for precooking chicken parts: Effects on yield and organoleptic quality. J. Food Sci., 38, 860863.

Egan, H; Rirk, R.S; \& Sawyer, R. (1981). Pearson's chemical analysis of foods. 8th ed. Churchill livingstone, Longman group limited.

Grau, A., Guardiola, F., Grimpa, S., Barroeta, A.C. \&, Codony, R. (2001a). Oxidative stability of dark chicken meat through frozen storage: Influence of

Fayoum J. Agric. Res. \& Dev., Vol.24, No.2, July, 2010 
dietary fat and $\alpha$-tocopherol and ascorbic acid supplementation. Poult. Sci $80,1630-1642$.

Grau, A., Codony, R., Grimpa, S., Baucells, M. D.,\& Guardiola, F. (2001b). Cholesterol oxidation in frozen dark chicken meat: influence of dietary fat source, and $\alpha$-tocopherol and ascorbic acid supplementation. Meat Sci. $57,197-208$.

Harrison, D.I. (1980). Microwave versus conventtional cooking methods: Effects on food quality attributes. J. Food Port. 43, 633-637.

Igene, J.O.; Pearson, A.M., \& Gray, J.I. (1981). Effects of length of frozen storage, cooking and holding temperatures upon component phospholipids and the fatty acid composition of meat triglycerides and phospholipids. Food Chem. 7, 289- 303.

Jensen, C., Lauridsen, C. \& Bertelsen, G. (1997). Dietary vitamin E: Quality and storage stability of pork and poultry. Trends Food Sci. Technol., 8, 62-72.

Kopp, P.M. (1973). Chemical changes in heated fats. Nutr. Dieta, 1970, 15,199-204. C.F. C.A., 75, 117311.

Lau, D. W.\&, King, A. J., (2003). Pre- and post-mortem use of grape seed extract in dark poultry meat to inhibit development of thiobarbituric acid reactive substances. Journal of Agricultural and Food Chemistry, 51, 1602-1607.

Lwasaki, L; Hasegawa, Y; Yamamoto, k; \& Nakamura, k. (2009). The relationship between changes in local stiffness of chicken myofibril and the tendrness of muscle during potmorten aging. Progr. Colleid Polym. Sci. 136: 205 - 210

Mehaffey, J. M., Pradhan, S. P., Meullenet, J. F., Emmert, J. L., Mckee,S. R.,\& Owens, C. M. (2006). Meat quality evaluation of minimally aged broiler breast from five commercial genetic strains. Poultry Science, 85, 902-908.

Melton, S.L. (1983). Methodology for following lipid oxidation in muscle foods. Food Technol., 37, 105-11, 116.

Metcalfe, L.D, Schmitz, A.A.,\& Pelka, J.R. (1963). Rapid preparation of fatty acid esters from lipids for gas chromatographic analysis.Anal. Chem., 38,514-515.

Metcalfe, L.D., \& Wang, C.N. (1981). Rapid preparation of fatty acid methyl esters using organic base-catalyzed transesterification. J. Chromatog. Sci., 19, 530535 .

Moawad, R.K. (1987). Effect of freezing and cooking on the chemical composition and biological quality of beef meat, M.Sc. Thesis, Faculty of Agric., Cairo Univ.

Moawad, R.K. (1995). Effect of pre-treatment on quality attributes and nutritive value of frozen beef and chicken meats, Ph.D. Thesis, Faculty of Agric., Cairo Univ.

Moore, S., Spackman, D.H.,\& Stein, W. (1958). Chromatography of amino acids on sulphonated polystyrene resins. Anal. Chem. 30, 1185-1190.

Morsi, M.K.S.; El-Wakeil, F.A.,\& Abo-Raya, S.H. (1975). Chemical and biological evaluation of fresh and preserved lake Naser's fish. 1- Frozen Bolti fish fillets (Tilapia sp.). Egypt. J. Food Sci., 3, 57.

Moussa, B.M. (1981). Chemical and biological evaluation of meat organs, Ph.D. Thesis, Faculty of Agric., Cairo Univ.

Nam, K. C., Du, M., Jo, C.,\& Ahn, D. U (2001). Cholesterol oxidation products in irradiated raw meat with different packaging and storage time. Meat Science, $58,431-435$.

Oroszvári, B.K., Sjöholm, I.,\& Tornberg, E., (2005). The mechanisms controlling heat and mass transfer on frying of beefburgers. Part I. The influence of the composition and comminution of raw meat material. Journal of Food Engineering, 67, $499-506$.

Fayoum J. Agric. Res. \& Dev., Vol.24, No.2, July, 2010 
Oroszvári, B.K., Rocha, C.S., Sjöholm, I.,\& Tornberg, E., (2006). Permeability and mass transfer as a function of the cooking temperature during the frying of beef burgers. Journal of Food Engineering, 74, $1-12$.

Pan, Z.,\& Singh, R. P. (2001). Physical and thermal properties of ground beef 1 during cooking. Lebensmittel-Wissenschaft und Technologie, 34, 437 - 444.

Pikul, J., Leszezynski, D.E., Bechtel, P.J.,\& Kummerow, F.A (1984). Effects of frozen storage and cooking on lipid oxidation in chicken meat. J. Food Sci., , 49, 838-843.

Rahman, S. M., Al-Belushi, M.R., Guizani, N. Al-Saidi, G. S.,\& Soussi, B., (2009). Fat oxidation in freeze-dried grouper during storage at different temperatures and moisture contents. Food Chemistry, 114, 1257-1264

Risch, S.A. (1989). Flavors for microwavable foods. Cereal Food World, 43, 226-229.

Self, K.P. Nute, G.R., Burfoot, D.,\& Monerieff, C.B. (1990). Effect of pressure cooking and pressure rate change during cooling in vacuum on chicken breast quality and yield. J. Food Sci., 55, 1531-1535, 1551.

Shams El-Din, M.H.A. \& Bayoumy, A.H. (1990 a). Effect of frozen storage on lipid stability in chicken muscles. Annals of Agric. Sci., Moshtohor, 28, 1115-1125.

Shams El-Din, M.H.A.,\& Ibrahim, H.M. (1990 b). Cooking effects on fat and fatty acids coposition of chicken muscles, Die Nahrung, 34, 207-212.

Shilton, N., Mallikarjunan, P. \& Sheridan, P., (2002). Modeling of heat transfer and evaporative mass losses during the cooking of beef patties using far-infrared radiation. Journal of Food Engineering, 55, $217-222$.

Shireva, R.A., Novikova, M.E.,\& Lobyanetski, S.A. (1979). Some qualitative changes of broilers meat when stored in the refrigerator. Food Technol., 129, $55-56$.

Snedecor, G.W.,\& Cochran, W.G. (1989). Statistical Methods., 8th ed. Iowa State Univ. Press, Ames, IA., USA.

Widner, K.,\& Eggum, B.O. (1966). Protein hydrolysis. A description of the method used at the department of animal physiology in Copenhagen. Acta Agricultural Scandinavia, 16, 115-118. C.F. The Method of Amino Acid Analyzer, Food and Feed Lab., Agric. Research Centre, Ministry of Agric., Giza, Egypt (1997).

Wood, J. D., Richardson, R. I., Nute, G. R., Fisher, A. V., Campo, M. M.,\& Kasapidou, E.. (2003). Effects of fatty acids on meat quality: a review. Meat Science, 66, 21-32.

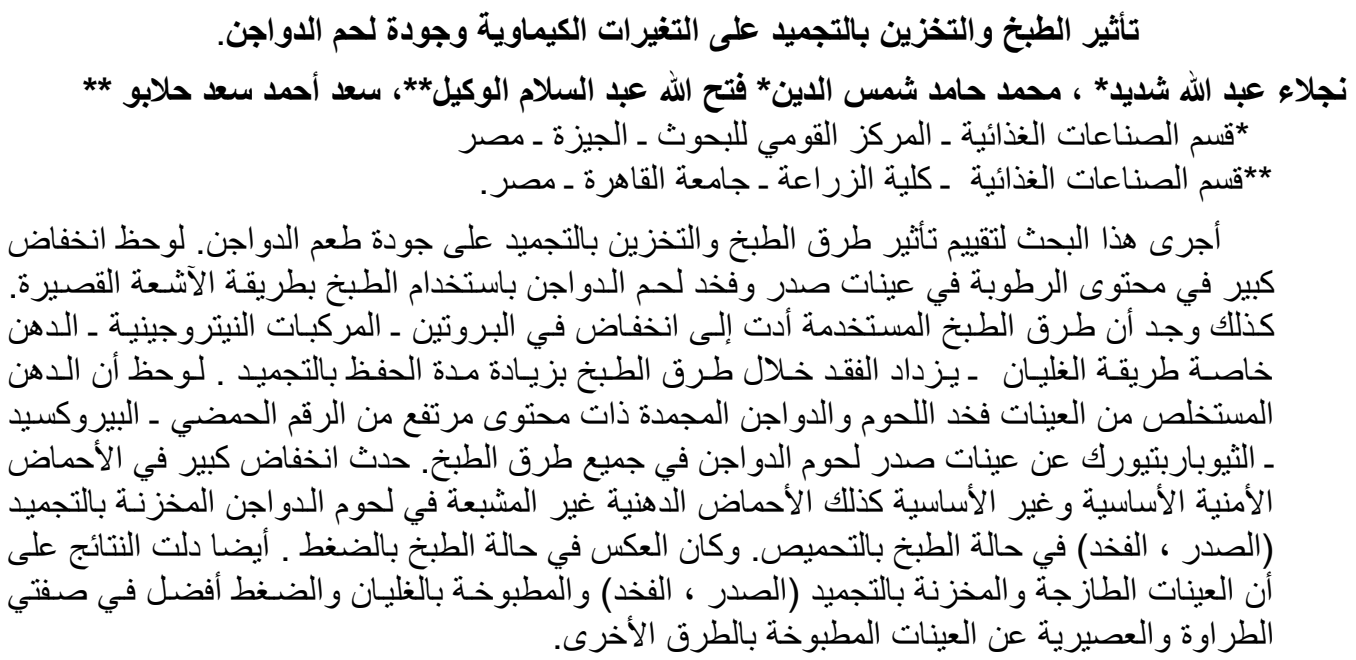

Fayoum J. Agric. Res. \& Dev., Vol.24, No.2, July, 2010 